\title{
DEPHOSPHORYLATION OF ADENOSINETRIPHOSPHATE BY NORMAL AND PATHOLOGICAL HUMAN SERA ${ }^{1}$
}

\author{
BY ALTON MEISTER \\ (From the National Cancer Institute, National Institute of Health, Bethesda, Maryland)
}

(Received for publication September 15, 1947)

\section{INTRODUCTION}

Recent studies indicate the importance of adenosinetriphosphate (ATP) in cellular metabolism. Adenosinetriphosphatase (ATP-ase), which catalyzes reaction $A$, has been found in a number of tissues.

$$
\begin{aligned}
& \text { A } \quad \text { ATP } \stackrel{\text { ATP-ase }}{\longrightarrow} \text { ADP } \\
& \text { B ADP } \stackrel{\text { ADP-ase }}{\longrightarrow} \text { Adenylic Acid } \\
& \text { + Inorganic Phosphate }
\end{aligned}
$$

Adenosinediphosphate (ADP) may be dephosphorylated to adenylic acid by adenosinediphosphatase (Reaction B). However, evidence for a specific ADP-ase is lacking and it is probable that the two-step dephosphorylation of ATP is catalyzed by the same enzyme (1). In muscle, ADP is converted to adenylic acid by the action of myokinase (1), in which labile phosphate is transferred from one molecule of ADP to another yielding one molecule each of ATP and adenylic acid (Reaction C).

ATP-ase has been found in muscle, liver, kidney, brain, other animal tissues, and in tumors (2), the highest concentrations being present in cardiac and skeletal muscle (3). Optimum ATPase activity has been found to occur at about $\mathrm{pH} 9$ (3 to 7). In the course of an investigation of the dephosphorylation of ATP by human serum, a rather definite $\mathrm{pH}$ optimum was observed in acid media, as well as the expected optimum at alkaline reaction (8). It appeared that splitting of ATP at acid $\mathrm{pH}$ was not due to acid phosphomonoesterase. The dephosphorylation of ATP at acid and alkaline values of $\mathrm{pH}$ has been investigated in a small group of human sera.

1 This study was carried out at Gallinger Municipal Hospital, Washington, D. C.

\section{MATERIALS AND METHODS}

Phosphorus was determined by the method of Fiske and Subbarow (9). Nitrogen analyses were carried out as described by Koch and McMeekin (10). Serum magnesium was determined according to a modification of the method of Denis (11). The glass electrode was employed for the measurement of $\mathrm{pH}$.

ATP was prepared from rabbit muscle as the barium salt by the method of Kerr (12). This was converted to the sodium salt by precipitation with the stoichiometric amount of sulfuric acid, the solution then being adjusted to $\mathrm{pH} 7$ with 'sodium hydroxide. The atomic ratio of nitrogen to phosphorus was $5.07: 3$, and that of acidlabile 2 to total phosphorus was $2.01: 3$. The muscle adenylic acid used in these experiments was prepared and characterized according to Ostern et al. (13), and further identified by the rate of color development with orcinol reagent (14).

Serum from patients and apparently healthy individuals was prepared from venous blood. Care was exercised to avoid hemolysis, which was found to increase the activity. In the studies reported, patients are referred to by number and the corresponding diagnoses are listed in Table I. The letter $\mathbf{N}$ appears before the numbers assigned to apparently healthy subjects.

Dephosphorylation of ATP was measured in a system designed to make the concentration of enzyme the ratedetermining factor. The usual procedure was as follows: All solutions were brought to $37^{\circ}$ before use. Fivetenths of a cubic centimeter of serum was added to 2.5 cc. of ATP in $0.1 \mathrm{M}$ veronal- $\mathrm{HCl}$ or acetate buffer, and mixed immediately. At the end of a given period of incubation at $37^{\circ}$ (usually from 0.5 to 2 hours), the reaction was stopped by the addition of 5 cc. of $8 \%$ trichloracetic acid. The mixture was filtered and a suitable aliquot of the clear filtrate was analyzed for inorganic phosphorus and, in certain experiments, for acid-labile phosphorus. Controls with buffer and ATP alone, and with serum and buffer alone were employed. Determinations were usually carried out in duplicate. In some cases different concentrations of serum or incubation periods were employed in order to check the method. Where the effects of various salts were studied, these compounds were dissolved in the buffer-substrate solution, and controls containing these salts were used. Measurements of $\mathrm{pH}$ were carried out on identical mixtures at $37^{\circ}$. The data presented below are corrected

2 Determined by hydrolysis with $\mathrm{N} \mathrm{HCl}$ at $100^{\circ}$ for 15 minutes. 


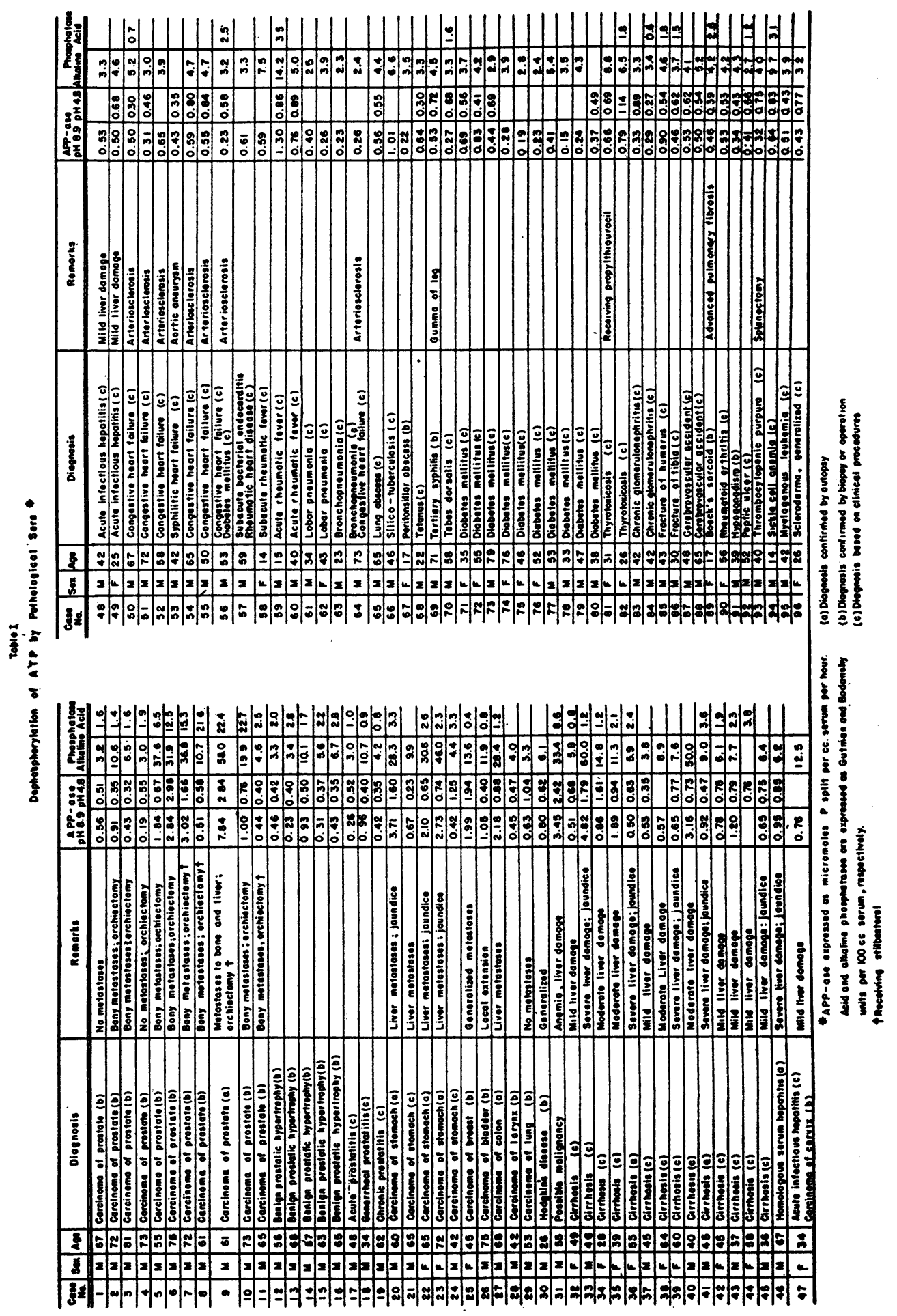


for serum inorganic phosphorus and nonenzymatic hydrolysis, and are expressed as micromoles of phosphorus split from ATP per cc. serum per hour, unless otherwise stated.

Serum alkaline and acid phosphatases were determined by the procedures of Bodansky (15) and Gutman (16), respectively, and are expressed in the customary units.

\section{RESULTS}

\section{pH-activity curves}

The liberation of inorganic phosphorus from ATP by human serum was found to exhibit optima in the ranges of $\mathrm{pH}$ from 4.6 to 5.1 and 8.7 to 9.1 . This was true with normal serum and serum with increased activity (Figures 1 and 2 ). In normal serum the two optima are of about the same order of magnitude, although frequently the activity at

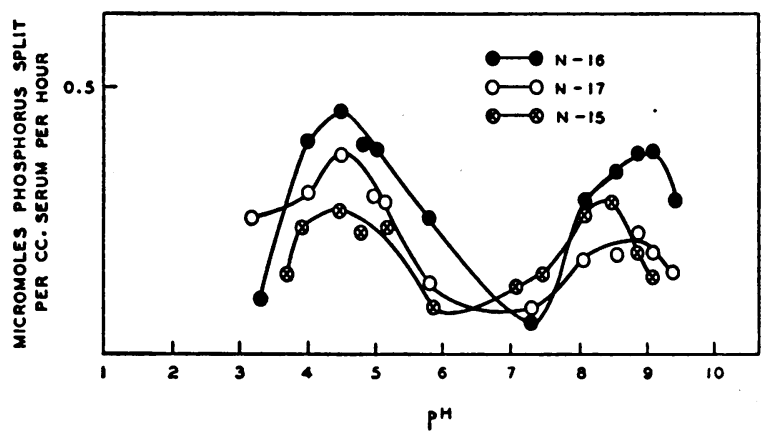

Fig. 1. pH-activity Curves for 3 Normal Human Sera, Carried out with 9.67 Micromoles of ATP

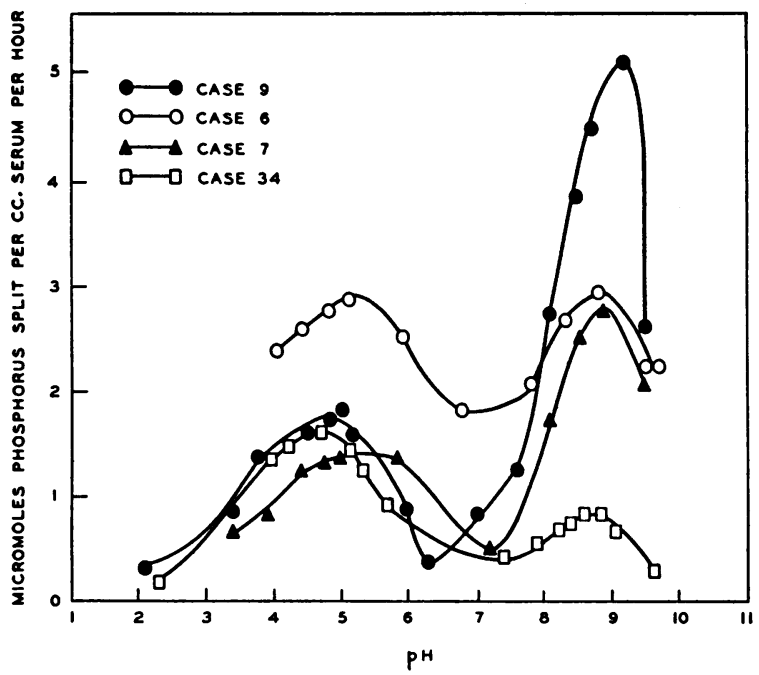

Fig. 2. pH-activity Curves for 4 Pathological Human Sera with Elevated Activity, Carried out With 9.67 Micromoles OF ATP acid $\mathrm{pH}$ was slightly greater. With certain pathological sera, however, the two activities were markedly different and showed no consistent relationship. The acid optimum was a constant finding in all human sera studied and similar data were obtained with $0.01 \mathrm{M}$ citrate buffers and with three different ATP preparations. Identical $\mathrm{pH}$ activity curves were observed with dialyzed serum. Subsequent studies were carried out at the $\mathrm{pH}$ optima, i.e., $\mathrm{pH} 4.8$ and 8.9 .

\section{Effect of substrate concentration}

Greater concentrations of substrate were found necessary for maximum activity at $\mathrm{pH} 4.8$ than at 8.9 (Table II). Usually between two and

TABLE II

Effect of substrate concentration *

\begin{tabular}{ccc}
\hline & \multicolumn{2}{c}{$\begin{array}{c}\text { Micromoles P split per cc. } \\
\text { serum per hour }\end{array}$} \\
ATP conc. & pH 4.8 & pH 8.9 \\
\hline micromoles & & \\
0.676 & 1.50 & 3.42 \\
1.35 & 1.92 & 5.54 \\
2.03 & 2.15 & 6.70 \\
2.71 & 2.30 & 7.64 \\
3.38 & 2.48 & 7.84 \\
4.06 & 2.40 & 7.68 \\
5.41 & 2.76 & 7.27 \\
6.76 & 2.88 & 7.37 \\
7.44 & 2.83 & 7.15 \\
8.79 & 2.80 & 7.80 \\
10.0 & 2.86 & 7.18 \\
12.2 & 2.84 & \\
\hline
\end{tabular}

* These data were obtained with serum of case 9.

three times as much ATP was required at $\mathrm{pH}$ 4.8 than at 8.9. In order to insure maximum activity, the studies described below were carried out with 3.38 and 9.67 micromoles of ATP at $\mathrm{pH}$ 8.9 and 4.8 , respectively, except as noted in certain experiments. The liberation of inorganic phosphorus was directly proportional to serum concentration and duration of incubation. With sera of high activity, shorter incubation periods or lower serum concentrations were employed.

\section{Dephosphorylation of ATP at pH 8.9}

On prolonged incubation practically all of the ATP phosphorus was liberated as inorganic phosphorus at $\mathrm{pH} 8.9$ (Figure 3, Table III). In addition the inorganic phosphorus produced was greater than the decrease in acid-labile phosphorus (Table III). The ratio of the decrease in 


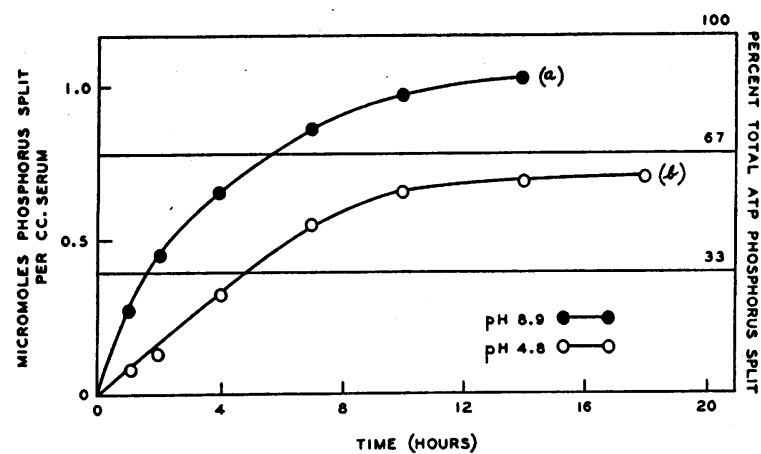

Fig. 3. Dephosphorylation of ATP by Normal Human Serum (Subject N-16) AT pH 8.9 (a) ANd $\mathrm{PH} 4.8$ (b)

Maximum hydrolysis is equivalent to 1.17 micromoles of inorganic $\mathbf{P}$.

TABLE III

Dephosphorylation of ATP at $p H 8.9^{*}$

\begin{tabular}{c|c|c|c|c}
\hline \hline Time & $\begin{array}{c}\text { Inorganic P } \\
\text { (A) }\end{array}$ & $\begin{array}{c}\text { Decrease in } \\
\text { acid-labile P } \\
\text { (B) }\end{array}$ & $\begin{array}{c}\text { Ratio } \\
\text { B/A }\end{array}$ & $\begin{array}{c}\text { Per cent } \\
\text { total P } \\
\text { split }\end{array}$ \\
\hline hours & micromoles & micromoles & & \\
0.5 & 1.62 & 1.07 & 0.660 & 24.5 \\
1.0 & 2.71 & 1.75 & 0.646 & 41.1 \\
2.0 & 4.19 & 2.78 & 0.663 & 63.5 \\
4.0 & 5.66 & 3.68 & 0.650 & 85.8 \\
8.0 & 6.11 & 3.96 & 0.648 & 92.6 \\
\hline
\end{tabular}

* These data were obtained with $1.0 \mathrm{cc}$. serum (case 5). Maximum hydrolysis $\approx 6.60$ micromoles inorganic $P$.

acid-labile phosphorus to inorganic phosphorus was, within experimental error, about two-thirds, suggesting that adenylic acid formed by splitting of labile phosphorus is completely hydrolyzed as soon as it appears. This was confirmed by studies in which serum was added to small amounts of adenylic acid under identical conditions of serum concentration, $\mathrm{pH}$, and duration of incubation. The splitting of adenylic acid by normal and pathological sera was usually complete under these conditions (Table IV). The term "alkaline adenosinepolyphosphatase" (alkaline APP-ase) will be used to represent the enzymatic liberation of phosphorus from ATP at $\mathrm{pH} \mathrm{8.9,} \mathrm{since} \mathrm{several}$ enzymes, including phosphomonoesterase, may be concerned in the splitting of ATP.

\section{Dephosphorylation of ATP at pH 4.8}

The hydrolysis of ATP at $\mathrm{pH} 4.8$ appeared to reach completion when about two-thirds of the total ATP phosphorus was split (Figure 3, curve
TABLE IV

Hydrolysis of adenylic acid *

\begin{tabular}{|c|c|c|c|c|c|c|c|}
\hline \multirow{4}{*}{$\begin{array}{l}\text { Case } \\
\text { No. }\end{array}$} & \multirow{3}{*}{$\begin{array}{l}\text { Alkaline } \\
\text { phos- } \\
\text { phatase } \\
\text { units }\end{array}$} & \multirow{3}{*}{$\begin{array}{c}\text { Acid } \\
\text { phos- } \\
\text { phatase } \\
\text { units }\end{array}$} & \multicolumn{2}{|c|}{ APP-ase } & \multicolumn{3}{|c|}{ Adenylic acid } \\
\hline & & & \multirow{2}{*}{$\begin{array}{l}\mathrm{pH} \\
8.9\end{array}$} & \multirow{2}{*}{$\begin{array}{l}\mathrm{pH} \\
4.8\end{array}$} & \multirow{2}{*}{ Added } & \multicolumn{2}{|c|}{ Split } \\
\hline & & & & & & $\begin{array}{l}\mathrm{pH} \\
8.9\end{array}$ & $\begin{array}{l}\mathrm{pH} \\
4.8\end{array}$ \\
\hline & (1) & (2) & (3) & (4) & (5) & (6) & (7) \\
\hline $\mathrm{N}-15$ & & & 0.22 & 0.34 & 0.17 & 0.17 & 0.01 \\
\hline N-16 & & & 0.34 & 0.45 & 0.17 & 0.17 & 0 \\
\hline 84 & 3.4 & 0.6 & 0.29 & 0.27 & 0.16 & 0.14 & 0 \\
\hline 92 & 3.6 & 1.2 & 0.41 & 0.66 & 0.16 & 0.16 & 0.02 \\
\hline 35 & 11.3 & 2.1 & 1.89 & 0.94 & $\begin{array}{l}0.32 \\
0.64\end{array}$ & $\begin{array}{l}0.28 \\
0.43\end{array}$ & $\begin{array}{l}0.05 \\
0.08\end{array}$ \\
\hline 15 & 5.6 & 2.2 & 0.31 & 0.37 & 0.16 & 0.18 & 0 \\
\hline 5 & 37.6 & 6.5 & 1.84 & 0.67 & $\begin{array}{l}0.16 \\
0.32 \\
0.64\end{array}$ & $\begin{array}{l}0.16 \\
0.32 \\
0.66\end{array}$ & $\begin{array}{l}0.03 \\
0.09 \\
0.09\end{array}$ \\
\hline 7 & 36.8 & 15.3 & 3.02 & 1.66 & 0.71 & 0.71 & 0.05 \\
\hline 8 & 10.7 & 21.6 & 0.51 & 0.58 & $\begin{array}{l}0.16 \\
0.32\end{array}$ & $\begin{array}{l}0.14 \\
0.32\end{array}$ & $\begin{array}{l}0.08 \\
0.15\end{array}$ \\
\hline 9 & 58.0 & 22.4 & 7.84 & 2.84 & $\begin{array}{l}1.20 \\
0.64\end{array}$ & 1.20 & $\begin{array}{l}0.34 \\
0.18\end{array}$ \\
\hline 10 & 19.9 & 22.7 & 1.00 & 0.75 & $\begin{array}{l}0.16 \\
0.32\end{array}$ & $\begin{array}{l}0.18 \\
0.32\end{array}$ & $\begin{array}{l}0.09 \\
0.15\end{array}$ \\
\hline
\end{tabular}

* Adenylic acid expressed as micromoles; experimental details given in text. APP-ase expressed as micromoles $\mathbf{P}$ split per cc. serum per hour.

b). The liberation of inorganic phosphorus was not appreciably greater than the decrease in acidlabile phosphorus (Table V), indicating that the splitting of ATP at $\mathrm{pH} 4.8$ stops with the formation of adenylic acid. This is confirmed by the finding that negligible to small amounts of adenylic acid were split by most sera (Table IV). Greater, but not complete dephosphorylation of this sub-

TABLE $V$

Dephosphorylation of ATP at pH $4.8^{*}$

\begin{tabular}{c|c|c|c}
\hline \hline Case No. & Time & Inorganic P & $\begin{array}{c}\text { Decrease in } \\
\text { acid-labile } \mathbf{P}\end{array}$ \\
\hline & hours & micromoles & micromoles \\
7 & 2 & 1.66 & 1.63 \\
7 & 5 & 3.40 & 3.26 \\
39 & 2 & 0.77 & 0.76 \\
35 & 2 & 0.96 & 0.90 \\
6 & 2 & 2.47 & 2.43 \\
25 & 2 & 1.94 & 1.90 \\
\hline
\end{tabular}

* These data were obtained with 0.5 cc. serum. 
strate occurred with sera with elevated values of acid phosphatase associated with metastasizing carcinoma of the prostate. The enzymatic liberation of phosphorus from ATP at $\mathrm{pH} 4.8$ will be designated as "acid adenosinepolyphosphatase" (acid APP-ase). In most cases this represents splitting of labile phosphorus and could therefore be termed adenylpyrophosphatase.

\section{Effects of salts and dialysis}

The effects of calcium chloride, magnesium sulfate, sodium fluoride, and sodium cyanide on serum APP-ase were studied (Table VI). No significant activation was observed in studies in which the concentration of calcium was varied between 0.1 and $0.0001 \mathrm{M}$. On the other hand, magnesium sulfate produced activation in some sera at $\mathrm{pH} 8.9$, while there was no effect in acid media. Identical results were obtained with magnesium chloride. Activation by magnesium was quite variable and was usually observed in sera with elevated activity, but not in normal sera. When present,

TABLE VI

Effect of salts *

\begin{tabular}{|c|c|c|c|c|c|c|}
\hline \multirow{2}{*}{$\begin{array}{c}\text { Salt } \\
.\end{array}$} & \multirow{2}{*}{$\begin{array}{l}\text { Case } \\
\text { No. }\end{array}$} & \multicolumn{2}{|c|}{ APP-ase pH 8.9} & \multirow{2}{*}{$\begin{array}{l}\text { Case } \\
\text { No. }\end{array}$} & \multicolumn{2}{|c|}{ APP-ase pH 4.8} \\
\hline & & $\begin{array}{l}\text { Without } \\
\text { salt }\end{array}$ & $\begin{array}{l}\text { With } \\
\text { salt }\end{array}$ & & $\begin{array}{l}\text { Without } \\
\text { salt }\end{array}$ & $\begin{array}{l}\text { With } \\
\text { salt }\end{array}$ \\
\hline$\vec{U}^{\infty}$ & $\begin{array}{c}N-5 \\
N-15 \\
6 \\
39 \\
5 \\
41\end{array}$ & $\begin{array}{l}0.31 \\
0.20 \\
1.73 \\
0.65 \\
2.01 \\
0.68\end{array}$ & $\begin{array}{l}0.36 \\
0.23 \\
1.80 \\
0.68 \\
2.05 \\
0.64\end{array}$ & $\begin{array}{c}N-15 \\
N-26 \\
9 \\
41 \\
42 \\
80\end{array}$ & $\begin{array}{l}0.29 \\
0.55 \\
2.48 \\
0.47 \\
0.78 \\
0.49\end{array}$ & $\begin{array}{l}0.29 \\
0.51 \\
2.49 \\
0.48 \\
0.71 \\
0.51\end{array}$ \\
\hline $\begin{array}{l}\text { ర్ } \\
\sum_{\infty}\end{array}$ & $\begin{array}{c}N-15 \\
N-22 \\
6 \\
39 \\
45 \\
7 \\
22\end{array}$ & $\begin{array}{l}0.20 \\
0.26 \\
1.73 \\
0.65 \\
0.65 \\
2.76 \\
2.02\end{array}$ & $\begin{array}{l}0.23 \\
0.26 \\
2.92 \\
1.14 \\
0.80 \\
3.58 \\
2.16\end{array}$ & $\begin{array}{c}N-16 \\
N-5 \\
N-25 \\
7 \\
41 \\
9 \\
22\end{array}$ & $\begin{array}{l}0.56 \\
0.32 \\
0.25 \\
1.78 \\
0.47 \\
2.40 \\
0.65\end{array}$ & $\begin{array}{l}0.53 \\
0.28 \\
0.23 \\
1.70 \\
0.46 \\
2.36 \\
0.62\end{array}$ \\
\hline 旡 & $\begin{array}{l}N-15 \\
N-5 \\
N-25 \\
33 \\
5 \\
45\end{array}$ & $\begin{array}{l}0.29 \\
0.29 \\
0.19 \\
4.82 \\
2.05 \\
0.65\end{array}$ & $\begin{array}{l}0.24 \\
0.27 \\
0.21 \\
4.65 \\
2.05 \\
0.64\end{array}$ & $\begin{array}{l}\text { N-16 } \\
\text { N-5 } \\
\text { N-25 } \\
24 \\
9 \\
22\end{array}$ & $\begin{array}{l}0.57 \\
0.32 \\
0.25 \\
1.17 \\
2.40 \\
0.65\end{array}$ & $\begin{array}{l}0.26 \\
0.16 \\
0.04 \\
0.51 \\
1.50 \\
0.25\end{array}$ \\
\hline$\underset{Z}{Z}$ & $\begin{array}{c}N-15 \\
N-5 \\
N-25 \\
41 \\
22 \\
9\end{array}$ & $\begin{array}{l}0.29 \\
0.29 \\
0.19 \\
0.76 \\
2.10 \\
4.18\end{array}$ & $\begin{array}{l}0.29 \\
0.28 \\
0.20 \\
0.61 \\
1.96 \\
3.48\end{array}$ & $\begin{array}{c}N-15 \\
N-5 \\
N-25 \\
24 \\
45 \\
9\end{array}$ & $\begin{array}{l}0.33 \\
0.32 \\
0.19 \\
1.17 \\
0.75 \\
2.10\end{array}$ & $\begin{array}{l}0.29 \\
0.32 \\
0.20 \\
1.17 \\
0.75 \\
2.10\end{array}$ \\
\hline
\end{tabular}

* Concentration of added salt was $0.001 \mathrm{M}$. APP-ase expressed as micromoles $\mathrm{P}$ split per cc. serum per hour.
TABLE VII

Effect of dialysis on serum $A P P$-ase *

\begin{tabular}{c|c|c|c|c}
\hline \multirow{2}{*}{ Case No. } & \multicolumn{2}{|c|}{$\mathrm{pH} 8.9$} & \multicolumn{2}{c}{$\mathrm{pH} 4.8$} \\
\cline { 2 - 5 } \cline { 3 - 5 } & Undialyzed & Dialyzed & Undialyzed & Dialyzed \\
\hline $\mathrm{N}-25$ & 0.19 & 0.23 & 0.27 & 0.28 \\
$\mathrm{~N}-17$ & 0.22 & 0.21 & 0.50 & 0.49 \\
21 & 0.66 & 0.67 & 0.23 & 0.26 \\
42 & 0.78 & 0.60 & 0.78 & 0.82 \\
41 & 0.92 & 0.99 & 0.54 & 0.59 \\
40 & 3.16 & 3.17 & 0.73 & 0.70 \\
9 & 5.17 & 5.17 & 1.77 & 1.89 \\
\hline
\end{tabular}

* APP-ase expressed as micromoles P split per cc serum per hour.

this effect was maximal with magnesium concentrations of $0.001 \mathrm{M}$. The reason for the variable effect of magnesium is not known. Determinations of serum magnesium revealed the reported normal levels of 1 to $3 \mathrm{mg}$. per $100 \mathrm{cc}$. (11), which would correspond to concentrations of 0.0000686 to $0.000206 \mathrm{M}$ under the present conditions. Relatively high concentrations of magnesium ( 0.01 to $0.1 \mathrm{M}$ ) inhibited all sera studied. Sodium fluoride $(0.001 \mathrm{M})$ produced marked inhibition at $\mathrm{pH}$ 4.8 , while the same concentration of this salt had no appreciable effect at $\mathrm{pH} 8.9$. Inhibition at $\mathrm{pH}$ 8.9 was noted, however, with $0.01 \mathrm{M}$ fluoride. Sodium cyanide $(0.001 \mathrm{M})$ inhibited sera of elevated activity but not normal sera at $\mathrm{pH} 8.9$, while $0.01 \mathrm{M}$ cyanide inhibited both normal and pathological sera. On the other hand, at $\mathrm{pH} 4.8$, concentrations of 0.001 to $0.01 \mathrm{M}$ cyanide had no significant effect.

In an attempt to determine the presence in serum of diffusible cofactors, activators, or inactivators, dialyzed sera were studied. Serum was dialyzed in cellophane sacs at $5^{\circ}$ for 48 hours against large volumes of distilled water. The small precipitate which forms was resuspended. No appreciable difference in activity was found between the controls (refrigerated at $5^{\circ}$ ) and the dialyzed sera (Table VII). In addition no loss in activity occurred in sera stored for 48 hours at $5^{\circ}$, nor in sera frozen at $-5^{\circ}$ for three or four days.

\section{Clinical studies}

Studies of 27 apparently normal individuals are summarized in Table VIII. The group was about equally divided between the sexes and the range 
TABLE VIII

$A P P$-ase of normal human sera $\dagger$

\begin{tabular}{lcc}
\hline \hline & pH 8.9 & pH 4.8 \\
\hline Number of subjects & 27 & 24 \\
Range & $0.13-0.66$ & $0.20-0.66$ \\
Mean & $0.31 \pm 0.1^{*}$ & $0.40 \pm 0.1$ \\
\hline
\end{tabular}

*Std. dev. $=\sqrt{\frac{\Sigma d^{2}}{(n-1)}}$.

† APP-ase expressed as micromoles of PIsplit per cc. serum per hour.

of age was 20 to 63 , the average age being 36 . Significant variation with age or sex was not apparent, although a larger study would be necessary to investigate this point specifically. For the purposes of the present discussion, values greater than 0.70 at $\mathrm{pH} 8.9$, and 0.80 at $\mathrm{pH} 4.8$ are considered to be elevated. ${ }^{3}$

Of the pathological sera studied at $\mathrm{pH} 8.9$, values above 0.70 were encountered in 31 cases, 23 of which exhibited clinical evidence of disease of liver or bone. All 13 cases with alkaline APPase greater than 1.30 had evidence of hepatic impairment or carcinoma of the prostate with bony metastases. Increased alkaline APP-ase was always associated with elevated alkaline phosphomonoesterase activity. All of the 31 cases with elevated alkaline APP-ase were found to have alkaline phosphatase values greater than 4 units, and 21 of these had values between 10 and 60 units. Although there were 29 cases with values of alkaline phosphatase greater than 4 units and normal levels of alkaline APP-ase, none of these exceeded 11 units and more than half were less than 6 units.

Of the pathological sera studied at $\mathrm{pH} 4.8,19$ were found to have APP-ase exceeding 0.80 , and 12 of these (and all of the 8 cases with values greater than 1.50) had clinical evidence of hepatic or bone disease. It is now well established that marked elevations of acid phosphatase occur exclusively in cases of metastasizing carcinoma of the prostate, although slightly increased levels occasionally occur in other diseases $(17,18)$. Elevated acid phosphatase was present in 6 cases of prostatic carcinoma with bony metastases and in one case where no definite diagnosis could be made (case 31 ). These values are lower than

3 Values of acid and alkaline phosphatase, greater than 4 units per $100 \mathrm{cc}$., are considered to be elevated. those of some of the reported cases probably because no patients with untreated advanced prostatic cancer were available for study. There appeared to be no consistent relationship between phosphomonoesterase and APP-ase at $\mathrm{pH} 4.8$. Elevated acid APP-ase was encountered in cirrhosis and in non-prostatic cancer, where a normal level of acid phosphatase would be expected and was found. Of the 14 cases with elevated acid APP-ase, in which acid phosphatase was also determined, only four exhibited elevated acid phosphatase. In three cases of prostatic cancer with increased acid phosphatase, the acid APP-ase was within the normal range.

Slight variations in the data obtained on several normal individuals were noted over a period of 4 to 6 months. In patients with high values of APP-ase somewhat greater fluctuations with time were noted. Insufficient data are available, however, to relate these changes to the clinical course.

\section{APP-ase of animal sera}

The effect of hydrogen ion concentration on the serum APP-ase of three animal species was investigated. The sera of 4 dogs, 5 rabbits, and 4 specimens of pooled rat serum were studied. Representative $\mathrm{pH}$-activity curves are given in Figure 4. Maximum activity occurred in the acid range with dog and rabbit sera, with only a small

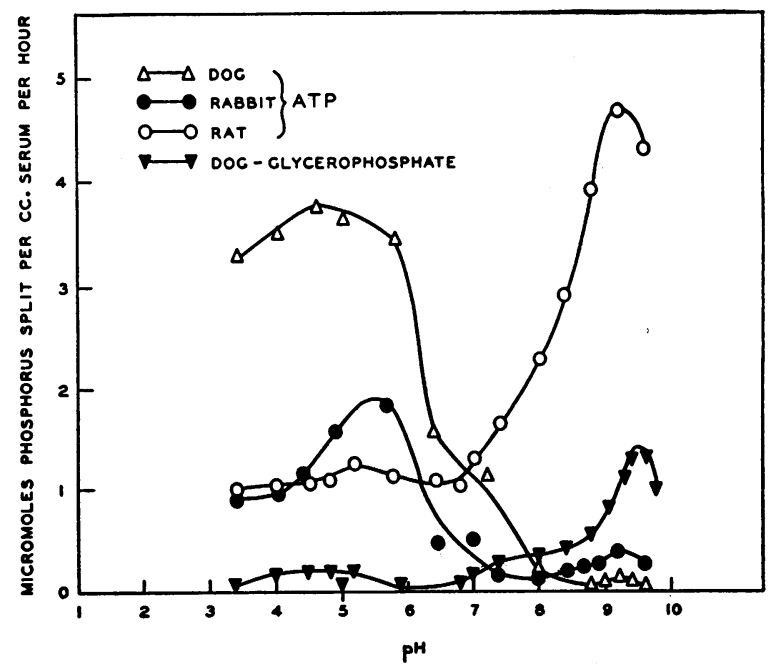

Fig. 4. pH-Activity Curves for Serum APP-Ase of Dog, Rabbit, and Rat, Carried out with 9.67 MicroMOLES OF ATP

The concentration of glycerophosphate was $0.025 \mathrm{M}$. 
peak at about $\mathrm{pH} 9$. In contrast, very high activity was found at $\mathrm{pH} 9$ with rat serum and only a slight elevation in the rather flat curve in the acid region. As opposed to the results obtained for dog serum APP-ase, the $\mathrm{pH}$-activity curve, with beta-glycerophosphate as the substrate, exhibited maximum activity at alkaline reaction. The latter $\mathrm{pH}$-activity curve is very similar to those reported for normal human serum glycerophosphatase (19). Experiments in which mixtures of dog and human sera were tested for APP-ase activity at $\mathrm{pH} 4.8$ yielded additive results.

\section{DISCUSSION}

Although a physical separation of acid and alkaline APP-ase was not attempted, it is probable that these activities represent different enzymes, as has been established for the phosphomonoesterases (20). There is no consistent relationship between the rates of dephosphorylation of ATP at pH 4.8 and 8.9 in various human and animal sera. More substrate is required to saturate acid APPase, and added salts $\left(\mathrm{MgSO}_{4}, \mathrm{NaF}, \mathrm{NaCN}\right)$ have different effects on the two activities. The Russian workers have reported that in addition to the prominent $\mathrm{pH}$ optimum at 9 , myosin preparations exhibit a second and lower optimum at $\mathrm{pH} 6.3$, the entire $\mathrm{pH}$-activity curve being equally lowered at all points by magnesium. A careful study led these authors to believe that the two optima were related to the dependence of activity upon the ionization of both enzyme and substrate, rather than to two different enzymes (21). This explanation does not appear applicable to the present results.

At $\mathrm{pH} 8.9$, splitting of ATP could be catalyzed by ATP-ase, an ADP-ase or myokinase, and phosphomonoesterase. At this $\mathrm{pH}$, adenylic acid is completely hydrolyzed and the rate-determining factor appears to be the splitting of labile phosphate. The values of adenylpyrophosphatase would therefore be two-thirds of those of APP ase. Except with sera of increased acid phosphatase content, the values of acid APP-ase are equivalent to adenylpyrophosphatase activity.

The range of values of beta-glycerophosphatase activity reported for normal human serum (15, 19) corresponds to $0-0.35$ and $0.48-1.28$ micromoles of phosphorus per cc. serum per hour for acid and alkaline phosphatase, respectively. The corresponding normal serum APP-ase values are therefore somewhat less at $\mathrm{pH} 8.9$ and slightly greater at $\mathrm{pH} 4.8$ (Table VIII). With pathological sera, less phosphorus was also split from ATP than from beta-glycerophosphate at alkaline $\mathrm{pH}$, and this difference was quite marked in certain cases. The acid APP-ase values, on the other hand, were higher than those of phenylphosphatase calculated on the same basis, in all but 3 (cases 5,8 , and 10 ) of the pathological sera studied.

The existence of a fairly specific ATP-ase active at alkaline $\mathrm{pH}$ is well established for muscle $(6,21)$. Purified myosin does not act upon inorganic pyrophosphate or monophosphates (6), but splits ATP, inosine triphosphate (22), and to some extent inorganic triphosphate (23). Jacobsen (24), Hasse (5), Barrenscheen and Lang (4), and Pillai (25) have reported evidence in support of a specific ATP-ase in liver, while Satoh (26) attributed the dephosphorylation of ATP to the combined action of pyrophosphatase and phosphomonoesterase.

At $\mathrm{pH} 8.9$ the dephosphorylation of ATP could be due to several enzymes including alkaline phosphatase. However, in view of the lack of correlation between APP-ase and phosphomonoesterase at $\mathrm{pH} 4.8$, it appears unlikely that acid phosphatase is responsible for ATP hydrolysis. Furthermore, with dog serum (Figure 4), the acid APP-ase was more than 16 times greater than the acid beta-glycerophosphatase activity. These findings are compatible with the recent work of MacLeod and Summerson (27). They report that a partially purified preparation of seminal fluid phosphatase was incapable of acting upon ATP, but they observed complete dephosphorylation of ATP by human seminal fluid. We have confirmed the latter finding, and have determined the $\mathrm{pH}$ optimum, which is in the neighborhood of 4 , for the APP-ase activity of two specimens of seminal fluid.

An "acid" adenylpyrophosphatase, present in serum and seminal fluid, and possibly other tissues, is suggested by the present data. The question of specificity, however, remains to be investigated. Although acid phosphatase of prostatic origin does not act upon ATP, the possibility has not been ruled out that other phosphomonoesterases, 
or even inorganic pyrophosphatase, may split ATP at acid $\mathrm{pH}$.

The absence of activation by calcium is of interest in view of the striking calcium activation reported with myosin $(6,7,21)$. Stimulation by calcium of ATP-ase but not beta-glycerophosphatase was reported by DuBois and Potter (3) for liver homogenates. Bailey (6) found that the activation by calcium of liver and electrical tissue ATP-ase was not as marked as with myosin. On the other hand, absence of calcium-activated ATP-ase was reported in rat muscle homogenates (28) and in chick embryos (29). It is possible that the concentration of calcium in serum is sufficient for maximum activity. Determinations of APP-ase of plasma prepared with $0.2 \%$ sodium oxalate revealed a slight and variable decrease in activity similar to the results reported for plasma phosphatase (15).

Magnesium increased the activity of certain pathological sera but had no effect with normal sera. Magnesium stimulates ATP hydrolysis by liver and electrical tissue $(3,6)$, and certain myosin preparations $(6,7)$, and has been shown to accelerate the conversion of ADP to adenylic acid $(1,6)$, and to activate alkaline phosphatase $(30)$. Since adenylic acid, under our conditions, is completely split by serum at $\mathrm{pH} 8.9$, in the absence of added magnesium, the most probable effect of magnesium is upon ADP breakdown. The inhibitory effect of higher concentrations of magnesium has also been observed in muscle and liver $(3,6)$.

Inactivation of ATP-ase by fluoride is well known. It is of interest that fluoride is a more efficient inhibitor at $\mathrm{pH} 4.8$ than at 8.9 , similar findings having been noted with acid phosphatase by Gutman (31). Cyanide has no effect on serum acid $\mathrm{APP}$-ase but inhibits at alkaline $\mathrm{pH}$. The latter finding was reported with $0.001 \mathrm{M}$ sodium cyanide for liver ATP-ase (4), but not with chick embryo systems (32) or myosin $(21,33)$.

The phosphomonoesterases normally present in serum are believed to be derived from at least several body tissues. Additional serum alkaline phosphatase in certain diseases probably arises from the bones and liver, while malignant prostatic tissue is considered to be the source of marked elevations of serum acid phosphatase. In view of the fact that elevated serum APP-ase was associated mainly with liver damage and bony metastases from prostatic carcinoma, it is quite possible that these tissues may be the source of the increased serum APP-ase. The variable effects of magnesium and cyanide with different sera may be due to qualitative differences in the APPase enzymes derived from different tissues, as has been noted for alkaline phosphatase $(34,35,36)$.

In view of the striking species differences in serum APP-ase, studies of various human and animal tissues might be expected to exhibit similar variation. Although it is possible that determinations of serum APP-ase may be of some diagnostic value, it is apparent that a study of a larger number of patients, with the above mentioned and other diseases, is necessary for a more complete evaluation of these studies and their relationship to the usual clinical phosphatase determinations.

\section{SUMMARY}

The dephosphorylation of ATP by normal and pathological human sera exhibits two $\mathrm{pH}$ optima at about 8.9 and 4.8. Hydrolysis of ATP at pH 8.9 is associated with the splitting of all three phosphate bonds of ATP and is probably due to several enzymes including alkaline phosphomonoesterase, although the hydrolysis of labile phosphate is apparently the rate-determining factor. Dephosphorylation of ATP at $\mathrm{pH} 4.8$ usually consists of splitting of the labile phosphate linkages, and the evidence suggests that this activity is not due to acid phosphatase. The existence of an "acid" adenylpyrophosphatase in serum, seminal fluid, and possibly other tissues, is suggested though not established.

The effects of substrate concentration, calcium, magnesium, fluoride, cyanide, and dialysis on the splitting of ATP by human serum are described. The $\mathrm{pH}$-activity curves for the dephosphorylation of ATP by several animal sera are given.

A study of ATP dephosphorylation and phosphomonoesterase in a small group of normal and pathological human sera was made. Elevated adenosinepolyphosphatase activity was frequently associated with liver disease and bony metastasis from prostatic carcinoma.

\section{BIBLIOGRAPHY}

1. Kalckar, H. M., Adenylpyrophosphatase and myokinase. J. Biol. Chem., 1944, 153, 355. 
2. Potter, V. R., and Liebel, G. J., Biocatalysts in cancer tissue. V. Adenosinetriphosphatase. Cancer Research, 1945, 5, 18.

3. DuBois, K. P., and Potter, V. R., The assay of ani$\mathrm{mal}$ tissues for respiratory enzymes. III. Adenosinetriphosphatase. J. Biol. Chem., 1943, 150, 185.

4. Barrenscheen, H. K., and Lang, S., Zur Kenntnis der Adenosintriphosphatase der Leber. Biochem. Ztschr., 1932, 253, 395.

5. Hasse, A., Uber die Spezifität der Adenylpyrophosphatase des Leberextraktes. Ztschr. f. physiol. Chem., 1936, 239, 1.

6. Bailey, K., Myosin and adenosinetriphosphatase. Biochem. J., 1942, 36, 121.

7. Singher, H. O., and Meister, A., The adenosinetriphosphatase activity of myosin preparations. J. Biol. Chem., 1945, 159, 491.

8. Meister, A., Adenosinetriphosphatase activity of human serum. Science, 1947, 106, 167.

9. Fiske, C. H., and Subbarow, Y., The colorimetric determination of phosphorus. J. Biol. Chem., 1925, 66, 375 .

10. Koch, F. C., and McMeekin, T. L., New direct nesslerization micro-Kjeldahl method and a modification of the Nessler-Folin reagent for ammonia. J. Am. Chem. Soc., 1924, 46, 2066.

11. Hawk, P. B., Oser, B. L., and Summerson, W. H., Practical Physiological Chemistry. Blakiston Co., Philadelphia, 1947, Ed. 12, p. 593.

12. Kerr, S. E., On the preparation of adenosinetriphosphate. J. Biol. Chem., 1941, 139, 121.

13. Ostern, P., Baranowski, T., and Terszakowéc, J., Uber die Phosphorylierung des Adenosins durch Hefe und die Bedeutung dieses Vorgangs für die alkoholische Gärung. II. Mitteilung. Ztschr. f. physiol. Chem., 1938, 251, 258.

14. Albaum, H. G., and Umbreit, W. W., Differentiation between ribose-3-phosphate and ribose-5-phosphate by means of the orcinol-pentose reaction. J. Biol. Chem., 1947, 167, 369.

15. Bodansky, A., Phosphatase studies. II. Determination of serum phosphatase. Factors influencing the accuracy of the determination. J. Biol. Chem., 1933, 101, 93.

16. Gutman, E. B., and Gutman, A. B., Estimation of "acid" phosphatase activity of blood serum. J. Biol. Chem., 1940, 136, 201.

17. Sullivan, T. J., Gutman, E. B., and Gutman, A. B., Theory and application of serum "acid" phosphatase determination in metastasizing prostatic carcinoma ; early effects of castration. J. Urol., 1942, 48, 426.

18. Woodard, H. Q., The interpretation of phosphatase findings in carcinoma of the prostate. N. Y. State J. of Med., 1947, 47, 379.

19. Shinowara, G. Y., Jones, L. M., and Reinhart, H. L., The estimation of serum inorganic phosphate and "acid" and "alkaline" phosphatase activity. J. Biol. Chem., 1942, 142, 921.

20. Perlmann, G. E., and Ferry, R. M., A note on the separation of kidney phosphatases. J. Biol. Chem., 1942, 142, 513.

21. Engelhardt, V. A., Adenosine triphosphate properties of myosin. Advances in Enzymology, 1946, 6, 147 (Interscience).

22. Kleinzeller, A., Adenosine- and inosine-neucleotides in the phosphorus metabolism of muscle. Biochem. J., 1942, 36, 729.

23. Needham, J., Kleinzeller, A., Miall, M., Dainty, M., Needham, D., and Lawrence, A. S. C., Is muscle contraction essentially an enzyme-substrate combination? Nature, 1942, 150, 46.

24. Jacobsen, E., Studien über die Stabilität und Trennbarkeit einiger Phosphatasen. Biochem. Ztschr., 1933, 263, 302.

25. Pillai, R. K., Dephosphorylation of adenosinetriphosphate in muscle extracts. Biochem. J., 1938, 32, 1087.

26. Satoh, T., Uber die Hydrolyse der Adenosintriphosphosäure durch Phosphomonoesterase und Pyrophosphatase. J. Biochem. (Japan), 1935, 21, 19.

27. MacLeod, J., and Summerson, W. H., The phosphatase activity of human spermatozoa. J. Biol. Chem., 1946, 165, 533.

28. Boyer, P. D., Lardy, H. A., and Phillips, P. H., Further studies on the role of potassium and other ions in the phosphorylation of the adenylic system. J. Biol. Chem., 1943, 149, 529.

29. Moog, F., and Steinbach, H. B., Adenylpyrophosphatase in chick embryos. . J. Cell. \& Comp. Physiol., 1945, 25, 133.

30. Bodansky, O., The effect of alpha amino acids and magnesium on the activity of kidney and intestinal phosphatases. J. Biol. Chem., 1936, 115, 101.

31. Gutman, E. B., and Gutman, A. B., Erythrocyte phosphatase activity in hemolyzed sera and the estimation of serum "acid" phosphatase. Proc. Soc. Exper. Biol. \& Med., 1941, 47, 513.

32. Steinbach, H. B., and Moog, F., Localization of adenylpyrophosphatase in cytoplasmic granules. J. Cell. \& Comp. Physiol., 1945, 26, 175.

33. Binkley, F., Ward, S. M., and Hoagland, C., Reversible inactivation of the adenosinetriphosphatase activity of myosin preparations with copper and cyanide. J. Biol. Chem., 1944, 155, 681.

34. Cloetens, R., Préparation et propriétés de la phosphatase "alcaline" I. Enzymologia, 1939, 7, 157.

35. Bodansky, O., Are the phosphatases of bone, kidney, intestine, and serum identical? The use of bile acids in their differentiation. J. Biol. Chem., 1937, $118,341$.

36. Drill, V. A., Annegers, J. H., and Ivy, A. C., Effect of cyanide, fluoride, and magnesium on the serum phosphatase activity during hepatic damage. $\mathrm{J}$. Biol. Chem., 1944, 152, 339. 